\title{
Acting in secret: Interaction, knowledge construction and sequential discussion patterns of partial role-assignment in a MOOC
}

\author{
Ken-Zen Chen \\ Institute of Education, National Yang Ming Chiao Tung University, Taiwan
}

\author{
Hsiao-Han Yeh \\ iKala Inc., Taiwan
}

\begin{abstract}
Forum discussions have been utilised widely as a means of facilitating learning interaction and social-knowledge construction in online learning. Much research has been conducted on the instructional interventions that benefit asynchronous discussions. Role-playing, or assigning roles to discussants, has been proven effective in promoting interactivity and knowledge construction in the context of both face-to-face and online learning. However, assigning and rotating roles to thousands of learners in massive open online courses (MOOCs) and preparing them to act properly in their roles sounds impractical to MOOC instructors due to work overload. The present study provided three types of role assignment in a MOOC during various course offerings: fall offerings with no role-assignment, spring offerings with partial role-assignment and summer offerings with full role-assignment. Through the examination of the discussion patterns and role-assignment differences among 4,239 students and 5,439 posts in 56 forums, we suggest that partial role-assignment is as effective as full-role assignment. By assigning as few as 10 students with rotating roles, MOOC instructors can leverage this effective strategy while minimising their effort in preparing the discussants and moderating the discussions. These students act behind the scenes and improve the behavioural patterns of asynchronous discussions.
\end{abstract}

Implications for practice or policy:

- MOOC instructors and teaching assistants can leverage a partial role-assignment strategy to improve asynchronous discussion quality with manageable effort.

- $\quad$ MOOC platform leaders and instructional designers may explore work-smart teaching strategies that are viable in practice without overburdening instructors.

Keywords: partial role-assignment, asynchronous online discussion forum, interaction, knowledge construction, MOOCs, lag sequential analysis

\section{Background}

Regardless of a face-to-face or online setting, discussion is both a key instructional tool as well as a critical learning strategy (Ellis \& Calvo, 2004; Hung et al., 2005). Proven effective discussion strategies include brainstorming, Phillips 66, task group, panel discussion, role-playing and Jigsaw (Gall \& Gall, 1976). One of the advantages of face-to-face discussion is the exchange of non-verbal clues among discussants (Tiene, 2000). However, asynchronous forum discussions are not without benefits. For example, participants have flexibility in time to integrate, clarify and elaborate their thoughts before posting a comment (Marra et al., 2004) and subsequently express synthesis and explorative ideas (Meyer, 2003). For those interactions - that is, student-content, student-student, student-teacher - (see Moore, 1989) to take place in online learning settings, asynchronous discussion boards would be the ideal platform to provide engaging, interactive and meaningful venues that eliminate transactional distance (Moore, 1972, 1997). Furthermore, online forums enable participation in communities of practice (Lave \& Wenger, 1991; Wenger, 1998), where learners generate ideas and actions that could be adapted to the ongoing environment.

Asynchronous discussion forums provide an unrestricted place for learner-learner and learner-instructor interactions (Dennen, 2005). An instructor as discussion leader is a vital person who questions, evaluates, responds to and encourages the discussion process (Orsolini \& Pontecorvo, 1992). For example, to make discussion a lively and engaging learning space, Gambrell (2004) recommended that in addition to giving feedback to every student, it is better for instructors to provide one overall comment at the end of the 
discussion. Meanwhile, instructors should not become over-engaged. Otherwise, they may destroy thr discussion flow since students would simply rely on instructor feedback (Palloff \& Pratt, 1999). Yilmaz and Yilmaz (2019) further suggested that online instructors should not micro-manage discussion flow, such as replying too often to the discussion or staying completely involved, but instead monitor closely and make their presence felt whenever needed.

The presence of forum hosts (usually, the course instructor) is the key to enhancing online discussion and learning quality (A. Cohen et al., 2019; Dennen et al., 2007; Mazzolini \& Maddison, 2003). Despite effective forum moderation promoting community-based inquiry and constructive learning (Garrison, 2017), discussion strategies are not commonly applied in massive open online courses (MOOCs). Early researchers have warned that the number of posts is unlikely to be an effective indicator of online engagement (Dawson, 2006; Swan et al., 2006). In fact, binding grades with required posts does not guarantee quality discussion (Hara et al., 2000), mainly because the workload of online instructors can easily escalate and reach unmanageable levels once enrolments increase (Berge, 1995). Online instructors and teaching assistants are expected to offer affective connections and create welcoming social climates (Oren et al., 2002). Early design manuals for MOOC instructors (e.g., University of Illinois, 2013; Vanderbilt University, n.d.) provided limited strategies for promoting online discussions (such as assigning points for a number of posts), and forum participants usually remain isolated, and individual voices remain unheard (Thomas, 2002). The major reason is that to read and respond to even a small portion of the posts when there are hundreds of weekly threads is particularly overwhelming for both instructors and students.

Since low instructor participation results in lower learner performance (Khalil \& Ebner, 2014), an alternative line of research was to develop instructor-free strategies that could still promote forum interactions. For example, E. G. Cohen (1994) used role assignments in traditional discussion settings to increase learner participation and interactions. De Wever et al. (2008) and De Wever et al. (2009) also successfully applied role assignments that promoted participation and interactions in asynchronous forum discussions. The present study generated insight regarding partial role-assignments to improve learners' discussion quality in MOOC forums and thus contributes to the developing body of research on MOOC teaching strategies.

\section{Literature review}

\section{Forum interaction in MOOCs}

According to Saah (2020), the founder of Class Central, learners in MOOCs exceeded 180 million in 2020. Although MOOC students are perceived as self-motivated learners who study in a learner-centred environment (Ash, 2012), they are likely to withdraw when feeling disconnected and dissatisfied (Hew, 2014). In a local celebration event held in Taiwan, MOOC learners who took the most courses shared that what motivates them to take more courses is the engaging and insightful interactions in forum discussions (C.-W. Wang, 2017). Literature has also shown that participation in MOOC forum discussions is low (A. Cohen et al., 2019), whereas more than half of MOOC completers actively participate in discussions (Breslow, Pritchard et al., 2013). Therefore, measuring interaction levels within computer-mediated communication (Rafaeli \& Sudweeks, 1997; Sproull \& Kiesler, 1986) would be a useful proxy for probing the experiences of online learners. We used a framework developed by Thomas (2002, p. 355). The framework (see Table 1) divides online interactions into four levels. The first two levels (IL1 and IL2) consist of merely monologues or superficial interactions; IL3 and IL4 describe learners socially negotiating and elaborating meanings in the threaded discussions. 
Table 1

Levels of interaction (Thomas, 2002, p. 355)

\begin{tabular}{ll}
\hline Category & Description \\
\hline Independent (IL1) & $\begin{array}{l}\text { Message makes no reference to other students' messages. } \\
\text { Quasi-interactive (IL2) }\end{array}$ \\
$\begin{array}{l}\text { Message refers to other student's messages, but only as a preliminary point } \\
\text { of reference before the student continues with their own isolated analysis. } \\
\text { Interactive-elaborative }\end{array}$ & $\begin{array}{l}\text { Message refers to another student's message and further develops the } \\
\text { theme. }\end{array}$ \\
(IL3) & $\begin{array}{l}\text { Message refers to another student's message and engages in negotiation or } \\
\text { Interactive-negotiating }\end{array}$ \\
(IL4) &
\end{tabular}

\section{Knowledge co-construction in forum discussions}

Online learning communities do not naturally happen in a vacuum (Conaway et al., 2005; Garrison, 2017). Proper instructor interventions, such as friendly visual presentations, clear expectations and positive learning culture (Garrison \& Cleveland. 2005; Garrison et al., 2010), are keys to knowledge coconstruction. Learning occurs through interacting with peers (Murphy, 1997) who consume and transform external information (Steffe \& Gale, 1995). With the most diverse learners compared to any other learning environment, MOOCs should be an ideal environment to exercise knowledge co-construction with discussion as a channel for participants to elaborate, listen, negotiate and co-construct knowledge and solutions to a problem (Stacey, 1999). Many theoretical frameworks have been proposed to analyse threaded discussions for knowledge construction (Rourke \& Anderson, 2004). Table 2 lists the major frameworks used in the literature.

Table 2

Theories and research of knowledge co-construction

\begin{tabular}{lll}
\hline Theoretical framework & Dimensions of knowledge co-construction & Research \\
\hline Analytic framework & Participative, social, interactive, cognitive, & Cohen et al. (2019); \\
(Henri, 1992) & metacognitive & Guasch et al. (2019); \\
& & Lämsä et al. (2020); \\
& & Jordan (2011); B. Zheng \& \\
& & Warschauer (2019)
\end{tabular}

Cognitive and constructive learningknowledge construction (P. Zhu, 1998)

Interaction analysis model (Gunawardena et al., 1997; derived from Henri, 1992)

Constructivist framework (Veerman et al., 2001)

Knowledge construction category system (Pena-Shaff \& Nicholls, 2004) Argumentative knowledge construction (Weinberger \& Fischer, comment, reflection, scaffolding

Sharing or comparing of information; discovery and exploration of dissonance or inconsistency among ideas, concepts, or statements; negotiation of meaning coconstruction of knowledge; testing and modification of proposed synthesis or coconstruction; agreement statements or applications of newly constructed meaning Not task-related (planning, technical, social, nonsense); task-related (new idea, explanation, evaluation) Question, reply, clarification, interpretation, conflict, assertion, consensus building, judgment, reflection, support, other

Participation, epistemic, argumentative, social mode
De Wever et al. (2009); Dubovi \& Tabak (2020); Floren et al. (2020); Hou (2012); Schellens et al. (2007)

Ak (2016); Avc1 (2020); Rehm et al. (2016)

Leskens et al. (2019); Shin \& Jung (2020); Shin et al. (2020)

Farrokhnia et al. (2019); S. Jiang et al. (2019); Yoon et al. (2020) 2006) 
Among these frameworks, Gunawardena et al.'s (1997) interaction analysis model, which was inspired by Henri's (1992) analytic framework, has been used widely in understanding online interactions in threaded discussions (e.g., YouTube comments; see Dubovi \& Tabak, 2020). Gunawardena et al.'s model focuses on learner interactions and describes a progression of knowledge construction through phases with corresponding increases in mental engagement of knowledge building. The advantage of the model is that it examines the social construction of knowledge by observable interaction phases (Floren et al., 2020). As shown in Table 3, Gunawardena et al. suggested that lower mental functions are associated with lower phases of knowledge construction ( $\mathrm{KC1}$ and 2) and higher mental functions are associated with higher phases of knowledge construction (KC3, 4 and 5). Given its focus on both interaction and knowledge construction, the interaction analysis model fits our research intent and was used as one of the coding schemes.

Table 3

Knowledge construction levels (Gunawardena et al., 1997, p. 414)

\begin{tabular}{|c|c|c|}
\hline Level & Description & Potential discussions \\
\hline \multirow[t]{5}{*}{ KC1 } & Sharing and & 1. A statement of observation or opinion \\
\hline & comparing of & 2. A statement of agreement from one or more other participants \\
\hline & information & 3. Corroborating examples provided by one or more participants \\
\hline & & 4. Asking and answering questions to clarify details of statements \\
\hline & & 5. Definition, description, or identification of a problem \\
\hline \multirow[t]{3}{*}{$\mathrm{KC} 2$} & Exploration of & 1. Identifying and stating areas of disagreement \\
\hline & dissonance & $\begin{array}{l}\text { 2. Asking and answering questions to clarify the source and extent of } \\
\text { disagreement }\end{array}$ \\
\hline & & $\begin{array}{l}\text { 3. Restating the participant's position and possibility of advancing } \\
\text { arguments or considerations in its support by references to the } \\
\text { participant's experience, literature, formal data }\end{array}$ \\
\hline \multirow[t]{5}{*}{$\mathrm{KC} 3$} & Negotiatic & 1. Negotiation or clarification of the meaning of terms \\
\hline & meaning & 2. Negotiation of the relative weight to be assigned to types of argument \\
\hline & & $\begin{array}{l}\text { 3. Identification of areas of agreement or overlap among conflicting } \\
\text { concepts }\end{array}$ \\
\hline & & $\begin{array}{l}\text { 4. Proposal and negotiation of new statements embodying compromise, } \\
\text { co-construction }\end{array}$ \\
\hline & & 5. Proposal of integrating or accommodating metaphors or analogies \\
\hline \multirow[t]{5}{*}{$\mathrm{KC} 4$} & $\begin{array}{l}\text { Testing } \\
\text { synthesis }\end{array}$ & $\begin{array}{l}\text { 1. Testing the proposed synthesis against "received fact" as shared by } \\
\text { the participants and/or their culture }\end{array}$ \\
\hline & & 2. Testing against existing cognitive schema \\
\hline & & 3. Testing against personal experience \\
\hline & & 4. Testing against formal data collected \\
\hline & & 5. Testing against contradictory testimony in the literature \\
\hline \multirow[t]{3}{*}{ KC5 } & Agreement & 1. Summarisation of agreements \\
\hline & statements and & 2. Application of new knowledge \\
\hline & applications & $\begin{array}{l}\text { 3. Metacognitive statements by the participants illustrating their } \\
\text { understanding that their knowledge or ways of thinking (cognitive } \\
\text { schema) have changed as a result of the conference interaction }\end{array}$ \\
\hline
\end{tabular}

Note. We added a KC6 code in the study to record off-topic discussions.

\section{Role assignment as proven effective in discussions}

Role assignment in asynchronous discussions is an effective learning scaffold (Wood et al., 1976) rooted in social constructivism (Vygotsky, 1978, as elaborated in W. Jiang, 2017). Instructors assign roles to the students participating in forums, elaborate role expectations and encourage them based on their assigned roles. Students do not forget their assigned roles and tend to act accordingly during the learning process (De Wever et al., 2008). Once learners are comfortable discussing in forums, the instructors remove the scaffold (i.e., role assignments; Doyle, 1986), and students are free to take any or no role to further discussions. Role assignment facilitates mutual dependency among students in online learning (Strijbos et al., 2004). Researchers have developed several role combinations and proven learning benefits, such as enhancing knowledge construction (De Wever et al., 2009; Hou, 2012; Schellens et al., 2007), promoting intensive participation (Schellens et al., 2007), helping to moderate domination of discussion by an 
individual (Jiang, 2017) and improving argumentation skills (Hou, 2012) when roles are introduced right at the beginning of the discussions (De Wever et al., 2009; Yilmaz \& Yilmaz, 2019). Considering Strijbos et al.'s advice that role designs should match the needs of classroom contexts, we reviewed role-assignment designs (see Table 4) and decided to use De Wever et al.'s (2008) roles in the MOOC we were offering.

Table 4

Role-assignment designs in discussions

\begin{tabular}{ll}
\hline Roles & Researchers \\
\hline Used in general contexts & \\
\hline $\begin{array}{l}\text { Starter and wrapper (wrap-up and } \\
\text { conclude action items) }\end{array}$ & Hara et al. (2000); Hill et al. (2009); P. Zhu (1998) \\
$\begin{array}{l}\text { Presenter, discussant, moderator } \\
\text { Moderator, theoretician, summariser, } \\
\text { source searcher }\end{array}$ & Smith \& Shotsberger (1997) \\
$\begin{array}{lc}\text { Starter, moderator, theoretician, source } \\
\text { searcher, summariser }\end{array}$ & W. Jiang (2017); Schellens et al. (2005) \\
& Cheng et al. (2014); De Wever et al. (2008); De Wever \\
& Yilmaz \& Yilmaz (2019) \\
\hline $\begin{array}{l}\text { Decision-maker, adviser, typist } \\
\begin{array}{l}\text { Project planner, communicator, editor, } \\
\text { data collector }\end{array}\end{array}$ & E. G. Cohen (1994); Hooper \& Hannafin (1988) \\
PhD student, supervisor & Strijbos et al. (2004) \\
\hline
\end{tabular}

There has been research on behavioural analysis methods to explore asynchronous discussion patterns (Hou $\& \mathrm{Wu}, 2011$; see also Tables 2 and 4), and sequential analysis enables verification and visualisation of sequential patterns of events or behaviour. Researchers have investigated knowledge construction and interaction in online discussions using statistical compilation of both the frequencies and sequences of coded discussions. After reviewing studies on assignment strategies for knowledge construction and interaction patterns of online discussions, a practical concern remains overlooked: How do MOOC instructors incorporate role-assignment strategies during the process of instruction while maintaining manageable workloads? Systematic reviews on MOOC research literature show that instructor-related empirical studies remain minimal (Veletsianos \& Shepherdson, 2016; M. Zhu et al., 2018, 2020). Our study fills this gap by highlighting a viable solution in the form of an effective forum intervention strategy for MOOC instructors.

\section{Research design}

This study followed a quantitative quasi-experimental design. Two analytical methods, quantitative content analysis (QCA; Henri, 1992) and lag sequential analysis (LSA), were employed. The social-knowledge construction and social interactions in the forums were explored by QCA and LSA after coding of the discussion messages. Furthermore, the differences between the discussion patterns of the no-, full- and partial role-assignment groups were also examined and visualised.

\section{Participants and context}

Tao of Learning (TOL), a redeveloped MOOC that meets the local needs of Chinese MOOC learners, is based on the English language MOOC - Coursera's Learning How to Learn - which features scientific meta-learning skills (Chen \& Oakley, 2020). A Moodle-based platform provider, ewant, offered support for TOL. The 7-week course offers course videos, small quizzes, discussions and an optional peer-review honour assignment. In addition to a welcome forum and course question and answer forums, there were seven course-related weekly forums with guiding questions in every offering. TOL is offered tri-annually; the fall and spring offerings target interest-based MOOC learners, and summer offerings are for-credit, general-education courses for college students. Additionally, a spring teacher education elective course (Learning and Reading Strategy) at the first author's institution uses TOL as course resources for flipped classrooms. Therefore, about 10-20 for-credit students who enrol in Learning and Reading Strategy participate in every spring TOL offering and learn together with typical MOOC learners. 


\section{Research questions}

As illustrated in Figure 1, the following research questions led our empirical observations:

1. What are the differences in interaction patterns among the three role-assigned groups?

2. What are the differences in knowledge construction patterns among the three role-assigned groups?

3. What are the interaction and knowledge construction sequences among the three role-assigned groups?

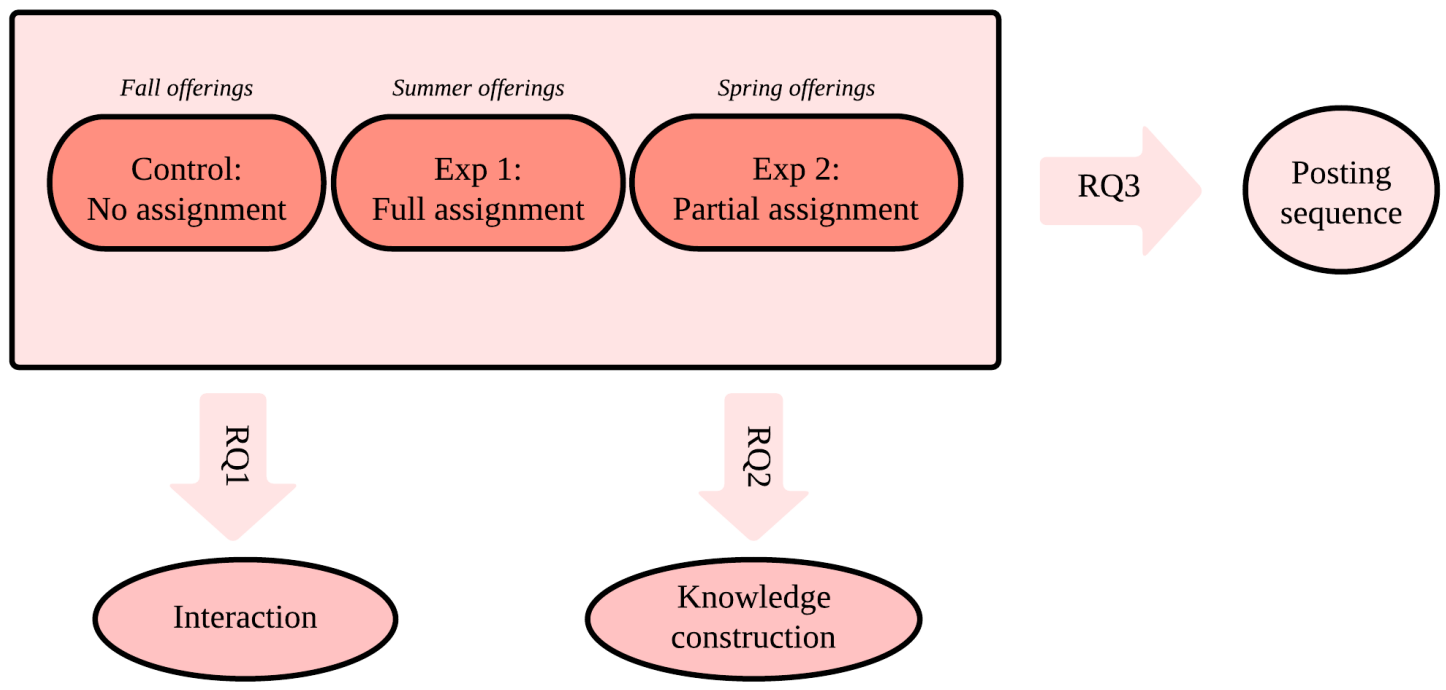

Figure 1. Research design and questions

\section{Quasi-experimental design}

To conduct the study, a quasi-experimental design was used. Three discussion configurations were assigned in corresponding offerings. The fall offerings served as a control group, where no role assignment was given to any students. The summer offerings served as the Experiment 1 group, where every student was assigned specific roles from Week 1 to Week 5 (see also Tables 5 and 7). Students were allowed to choose roles in Weeks 6 and 7 discussions. Again, the spring offerings served as the Experiment 2 group, where only the for-credit students were assigned roles and other interest-based learners were not. The detailed experimental assignment is illustrated in Table 5.

Table 5

Experimental assignment

\begin{tabular}{llccccccc}
\hline Group & Semesters & \multicolumn{2}{c}{ Enrolments } & \multicolumn{2}{c}{ No. of posts } & \multicolumn{2}{c}{ Posts/person } & Pass rate $(\%)$ \\
\hline No & Fall & Year & No. & Year & No. & Year & No. & \\
\cline { 2 - 7 } assignments & $(2017-2019)$ & 2017 & 1,576 & 2017 & 876 & 2017 & 0.56 & $191(12.1 \%)$ \\
& & 2018 & 369 & 2018 & 202 & 2018 & 0.55 & $41(11.1 \%)$ \\
& & 2019 & 362 & 2019 & 168 & 2019 & 0.46 & $50(13.8 \%)$ \\
\cline { 2 - 7 } & & Total & 2,307 & Total & 1,246 & Total & 0.54 & $282(12.2 \%)$ \\
\hline Full & Summer & 2018 & 147 & 2018 & 1,519 & 2018 & 10.33 & $101(68.7 \%)$ \\
assignments & $(2018,2020)$ & 2020 & 71 & 2020 & 639 & 2020 & 9.00 & $50(70.4 \%)$ \\
\cline { 3 - 7 } (Exp 1) & & Total & 218 & Total & 2,158 & Total & 9.90 & $151(69.3 \%)$ \\
\hline Partial & Spring & 2018 & 477 & 2018 & 597 & 2018 & 1.25 & $56(11.7 \%)$ \\
assignments & $(2018-2020)$ & 2019 & 646 & 2019 & 431 & 2019 & 0.67 & $74(11.5 \%)$ \\
(Exp 2) & & 2020 & 591 & 2020 & 1,007 & 2020 & 1.70 & $100(16.9 \%)$ \\
\cline { 3 - 6 } & & Total & 1,714 & Total & 2,035 & Total & 1.19 & $230(13.4 \%)$ \\
\hline
\end{tabular}

Note. Number of for-credit students in partial assignments: 12 (2018), 9 (2019) and 25 (2020). 
All learners in the summer semesters were randomly assigned a role rotation when TOL began and were instructed according to De Wever et al. (2008; see also Table 6). For example, Student C started with being a source searcher in Week 1 and then changed to be a summariser in Week 2. Since all learners would have experienced all five roles, they were told to choose freely any of the five roles and participate in the Weeks 6 and 7 forums. During the discussion, revealing their roles was not necessary. However, a short reflection about discussion participation was required as additional homework for these for-credit students, the purpose of which was to remind them to act based on their given roles.

Table 6

Example of rotation of student roles

\begin{tabular}{lllllll}
\hline Student & Week 1 & Week 2 & Week 3 & Week 4 & Week 5 & Weeks 6 \& 7 \\
\hline A & Starter & Moderator & Scholar & Searcher & Summariser & \\
B & Summariser & Starter & Moderator & Scholar & Searcher & \\
C & Searcher & Summariser & Starter & Moderator & Scholar \\
D & Scholar & Searcher & Summariser & Starter & Moderator & \\
E & Moderator & Scholar & Searcher & Summariser & Starter \\
F & Starter & Moderator & Scholar & Searcher & Summariser \\
G & Summariser & Starter & Moderator & Scholar & Searcher \\
\hline
\end{tabular}

Note. In Weeks 6 \& 7, students chose their own roles.

Across the eight course offerings in the study, enrolments totalled 4,239 learners, and there were 5,439 posts in 56 discussion boards. The study reviewed ethics approval from the Institutional Review Board of National Chiao Tung University under case number NCTU-REC-107-104.

Table 7

Roles in TOL based on De Wever et al. (2008)

\begin{tabular}{|c|c|c|}
\hline Role & Task in TOL & Sample excerpts from Forum 34 \\
\hline Starter & $\begin{array}{l}\text { Presenting an icebreaker, initiating a } \\
\text { welcoming discussion climate, posing } \\
\text { interesting questions, offering personal } \\
\text { stories to begin discussions }\end{array}$ & $\begin{array}{l}\text { I have a personal story. My Japanese teacher } \\
\text { had weekly quizzes. However, she tends to } \\
\text { ask us only when we feel prepared, then } \\
\text { takes the quiz. You can keep reading if you } \\
\text { don't feel ready to take the quiz. I was } \\
\text { confused ... }\end{array}$ \\
\hline Moderator & $\begin{array}{l}\text { Overseeing the discussion flows, } \\
\text { sharing constructive and/or critical } \\
\text { feedback to deepen discussions }\end{array}$ & $\begin{array}{l}\text { I agree that taking exams should be a fair } \\
\text { game; taking smart pills is like doping in the } \\
\text { Olympics. However, could that be a } \\
\text { demand-supply issue? We cannot overlook } \\
\text { that everyone wants a good grade, takes } \\
\text { every effort, and prepares until the exam } \\
\text { day. Taking smart pills is still different from } \\
\text { cheating in exams. What do you think? }\end{array}$ \\
\hline Theoretician & $\begin{array}{l}\text { Facilitating discussions based on } \\
\text { scholarly literature and evidence }\end{array}$ & $\begin{array}{l}\text { Much literature has indicated that paper- } \\
\text { and-pencil exams test reflect nothing about } \\
\text { prolonged understanding or learning. We are } \\
\text { trained to react mechanically to test } \\
\text { questions, but do not learn the substance of } \\
\text { knowledge. Smart pills are just the tip of the } \\
\text { iceberg. }\end{array}$ \\
\hline Searcher & $\begin{array}{l}\text { Offering resources (e.g., videos, blogs, } \\
\text { apps or infographics) that have } \\
\text { information related to discussion }\end{array}$ & $\begin{array}{l}\text { I did a quick search and found that the FDA } \\
\text { issued a notice, which clarified that the so- } \\
\text { called "smart pills" do not enhance our } \\
\text { cognitive capacity. You can read more at } \\
\text { https://www.fda.gov ... }\end{array}$ \\
\hline Summariser & $\begin{array}{l}\text { Summarising and concluding what can } \\
\text { be learned in the forum discussion }\end{array}$ & $\begin{array}{l}\text { It seems like that most people disagree using } \\
\text { smart pills. A few reasons stand out among } \\
\text { the threads. First of all ...; secondly ... }\end{array}$ \\
\hline
\end{tabular}




\section{Data analysis}

Discussion threads were extracted by an ewant technician, and each post was treated as a unit for analysis. We obtained 5,439 posts in eight TOL offerings (see Table 5). The coded data were then chronologically recorded for sequential analysis.

\section{Inter-coder reliability}

Three coders were invited in the study. The first coder (Coder A) is the second author, who conducted a pilot study in her master's thesis (Yeh, 2019), and the other two have served as teaching assistants for TOL for years (Coders B and C). Coder A conducted several training sessions with Coders B and C regarding the use of interaction (Table 1) and knowledge construction (Table 3). Given that a large number of posts were to be coded, we designed a four-phase inter-coder monitoring protocol to ensure coders had prolonged consensus. From the 56 forums, 20 were randomly picked. First, Coders B and C coded the first four forums, and their Cohen's kappa coefficients were calculated accordingly. Second, Coder A joined and coded the fifth forum with Coders B and C, and Fleiss' kappa (1971) was calculated. A training session was conducted immediately, and three coders reviewed and discussed the framework of Gunawardena et al. (1997) and Thomas (2002). Third, the coders again used another five randomly picked forums to repeat the first two steps, and kappa coefficients were calculated to review their consensus in the new phase until the 20 randomly selected forums were coded. Lastly, the coders reached very good or at least good agreement; thus, we considered the inter-coder reliability had been met. Then Coders B and C divided the remaining 36 forums and coded them individually. Table 8 shows the inter-coder reliability.

Table 8

Kappa statistics for agreement among coders

\begin{tabular}{|c|c|c|c|c|c|}
\hline $\begin{array}{l}\text { Rating } \\
\text { phase }\end{array}$ & $\begin{array}{l}\text { Forum swift } \\
\text { number }\end{array}$ & Coder assignment & $\begin{array}{l}\text { No. of posts } \\
\text { coded }\end{array}$ & $\begin{array}{l}\text { Kappa } \\
\text { coefficient }\end{array}$ & $\begin{array}{l}\text { Strength of } \\
\text { agreement }\end{array}$ \\
\hline \multirow[t]{5}{*}{$1(\mathrm{IN})$} & 1 & $B \& C$ & 273 & 0.71 & good \\
\hline & 2 & $B \& C$ & 122 & 0.86 & very good \\
\hline & 3 & $B \& C$ & 116 & 0.85 & very good \\
\hline & 4 & $B \& C$ & 115 & 0.86 & very good \\
\hline & 5 & $A, B \& C$ & 91 & 0.83 & very good \\
\hline \multirow[t]{5}{*}{$2(\mathrm{KC})$} & 6 & $B \& C$ & 109 & 0.90 & very good \\
\hline & 7 & $B \& C$ & 85 & 0.62 & good \\
\hline & 8 & $B \& C$ & 50 & 0.65 & good \\
\hline & 9 & $B \& C$ & 32 & 0.69 & good \\
\hline & 10 & $A, B \& C$ & 31 & 0.60 & good \\
\hline \multirow[t]{5}{*}{$3(\mathrm{IN})$} & 11 & $B \& C$ & 24 & 0.79 & good \\
\hline & 12 & $B \& C$ & 22 & 0.52 & moderate \\
\hline & 13 & $B \& C$ & 26 & 0.94 & very good \\
\hline & 14 & $B \& C$ & 24 & 0.83 & very good \\
\hline & 15 & $A, B \& C$ & 138 & 0.79 & good \\
\hline \multirow[t]{5}{*}{$4(\mathrm{KC})$} & 16 & $B \& C$ & 98 & 0.80 & good \\
\hline & 17 & $B \& C$ & 62 & 0.77 & good \\
\hline & 18 & $B \& C$ & 65 & 0.81 & very good \\
\hline & 19 & $B \& C$ & 57 & 0.73 & good \\
\hline & 20 & A, B \& C & 57 & 0.87 & very good \\
\hline
\end{tabular}

Note. Cut-off scale of kappa value is based on Altman (1991). Poor: $\boldsymbol{\kappa}<0.20$, fair: $\boldsymbol{\kappa}=0.21-0.40$, moderate: $\boldsymbol{\kappa}=0.41-$ 0.60 , good: $\boldsymbol{\kappa}=0.61-0.80$, very good: $\boldsymbol{\kappa}=0.81-1.00 . \mathrm{KC}=$ knowledge construction, IL $=$ interaction level.

\section{Chi-square test for independence}

A traditional code and count approach (Friend Wise \& Paulus, 2016) was initially used to compare discussion discrepancy among the three role assignments to evaluate how this instructional condition affects the qualities of discussions. The chi-square test for independence was used in the analysis.

LSA

LSA is widely used in the understanding of forum discussions (Hou, 2012, 2015; Hou \& Wu, 2011; Reimann et al., 2014; Sun et al., 2017; S. M. Wang et al., 2016; Wu \& Hou, 2015; Wu et al., 2016). The sequential analysis uncovered significant behavioural transfer sequences from one coding item to another. 
We were eager to investigate whether the discussion sequence of a forum followed by a certain discussion behaviour is significant. We recorded the behaviours of interest based on established coding schemes and analysed the relationship among behaviours by exploring significant sequences. With LSA, we captured the discussion processes among the online learners (Hou, 2010; L. Zheng \& Yu, 2016), differentiated online learning patterns among groups (Hou, 2012; L. Zheng \& Yu, 2016) and identified how students learn asynchronously (Hou, 2010, 2012; L. Zheng \& Yu, 2016). Event recording, one of the four behaviour codes defined by Bakeman and Gottman (1997), was used in the study. Only the behavioural sequences with $z$ score higher than 1.96 were considered as statistically significant ( $p$ value $<0.05$ ).

\section{Findings}

\section{Difference in forum interaction levels among groups}

The ANOVA test showed a significant difference of the average posts per person among groups $(F=390.85$, $d f=2, p=0.000)$, and the post-hoc comparison revealed that learners in summer semesters posted significantly more than those in both spring and fall offerings. Further, a chi-square test of independence was calculated comparing the frequency of interaction level in different role assignments. A significantly moderate association was found, $\chi^{2}(d f=6, N=5,348)=252.12, p=0.00$ and Cramer's $V=0.146$ with $p$ $=0.00$. As shown in Table 9 and Figure 2, as role assignments changed, interaction levels changed. IL2 and IL3 increased under partial and full assignments. A further comparison between partial and full assignments revealed no statistical differences among interaction levels, $\chi^{2}(d f=3, N=4,102)=5.05, p=0.17$.

Table 9

Results of role assignments for interaction level

\begin{tabular}{lcccccc}
\hline Interaction level & \multicolumn{2}{c}{ No assignment } & \multicolumn{2}{c}{ Partial assignment } & \multicolumn{2}{c}{ Full assignment } \\
& Frequency & Percentage & Frequency & Percentage & Frequency & Percentage \\
\hline IL1 & 1,057 & $84.8 \%$ & 1,272 & $65.4 \%$ & 1,344 & $62.3 \%$ \\
IL2 & 150 & $12.0 \%$ & 583 & $30 \%$ & 705 & $32.7 \%$ \\
IL3 & 21 & $1.7 \%$ & 78 & $4 \%$ & 98 & $4.5 \%$ \\
IL4 & 18 & $1.4 \%$ & 12 & $0.6 \%$ & 10 & $0.5 \%$ \\
\hline Total & 1,246 & $99.9 \%$ & 1,945 & $100 \%$ & 2,157 & $100 \%$ \\
\hline
\end{tabular}

Note. IL1 = independent, IL2 = quasi-interactive, IL3 = interactive-elaborative, IL4 = interactive-negotiating. $\chi^{2}(6$; $5,348)=252.12 ; p=0.00$

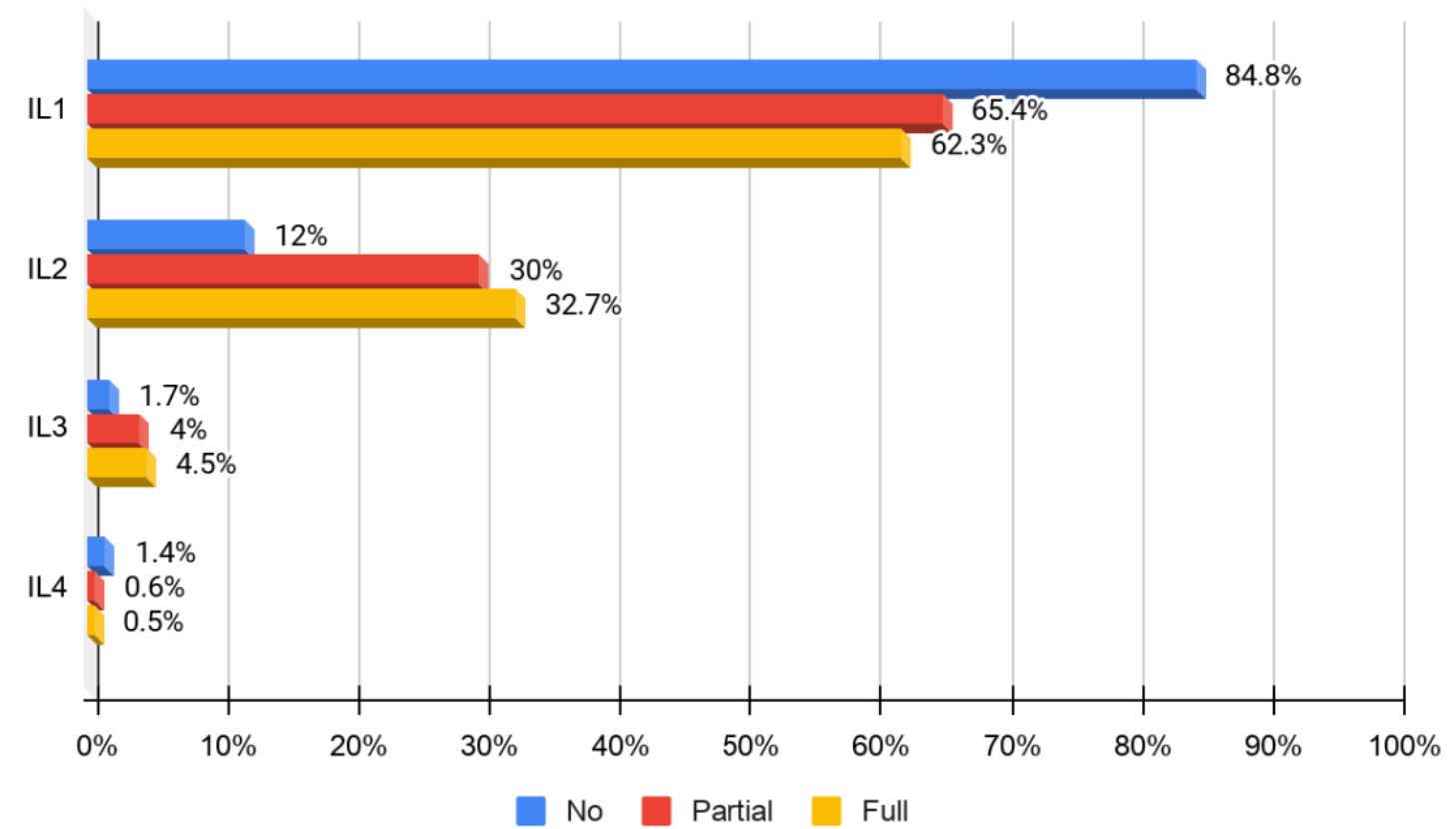

Figure 2. Interaction level among three assignments

Note. IL1 = independent, IL2 = quasi-interactive, IL3 = interactive-elaborative, IL4 = interactive-negotiating. 


\section{Difference in knowledge construction levels among groups}

Another chi-square test of independence was calculated comparing the frequency of knowledge construction in different role assignments. A significantly moderate interaction was found, $\chi^{2}(d f=10, N$ $=5,348)=535.55, p=0.00$ and Cramer's $V=0.224$ with $p=0.00$. As shown in Table 10 , as role assignment changed, knowledge construction behaviour changed. Both partial and full assignments had 20\% 30\% fewer $\mathrm{KC} 1$ than no assignments, but more $\mathrm{KC} 2, \mathrm{KC} 3$ and $\mathrm{KC} 4$. A further comparison between partial and full assignments revealed significant differences among knowledge constructions, $\chi^{2}(d f=5, N=4,102)=$ $170.68, p=0.00$. As shown in Figure 3, learners in partial assignments posted more KC1, KC4 and KC5 threads, while learners in full assignments posted more $\mathrm{KC} 2$ and $\mathrm{KC} 3$ threads.

Table 10

Results of role assignments for knowledge construction

\begin{tabular}{lcccccc}
\hline $\begin{array}{l}\text { Knowledge } \\
\text { construction }\end{array}$ & \multicolumn{2}{c}{ No assignment } & \multicolumn{2}{c}{ Partial assignment } & \multicolumn{2}{c}{ Full assignment } \\
& Frequency & Percentage & Frequency & Percentage & Frequency & Percentage \\
\hline KC1 & 854 & $68.5 \%$ & 910 & $46.8 \%$ & 834 & $38.7 \%$ \\
KC2 & 66 & $5.3 \%$ & 277 & $14.2 \%$ & 527 & $24.4 \%$ \\
KC3 & 73 & $5.9 \%$ & 218 & $11.2 \%$ & 376 & $17.4 \%$ \\
KC4 & 150 & $12 \%$ & 440 & $22.6 \%$ & 304 & $14.1 \%$ \\
KC5 & 67 & $5.4 \%$ & 74 & $3.8 \%$ & 41 & $1.9 \%$ \\
KC6 & 36 & $2.9 \%$ & 26 & $1.3 \%$ & 75 & $3.5 \%$ \\
\hline Total & 1,246 & $100 \%$ & 1,945 & $99.9 \%$ & 2,157 & $100 \%$ \\
\hline
\end{tabular}

Note. $\mathrm{KC} 1=$ sharing and comparing of information, $\mathrm{KC} 2=$ exploration of dissonance, $\mathrm{KC} 3=$ negotiation of meaning, $\mathrm{KC} 4=$ testing synthesis, $\mathrm{KC} 5=$ agreement statements and applications, KC6 $=$ off-topic discussions. $\chi^{2}(10 ; 5,348)=$ $535.55 ; p=0.00$

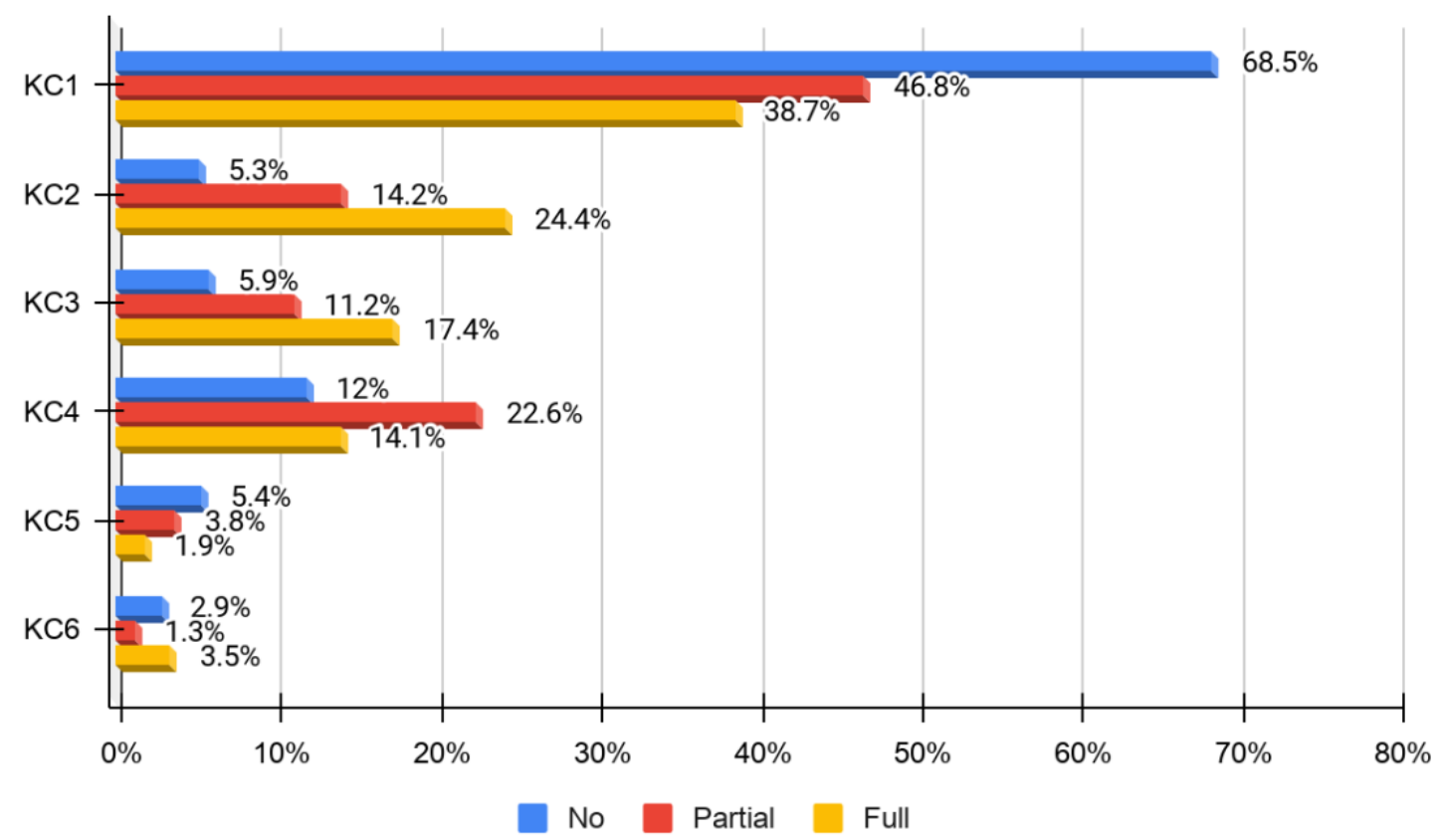

Figure 3. Knowledge construction among three assignments

Note $\mathrm{KC} 1=$ sharing and comparing of information, $\mathrm{KC} 2=$ exploration of dissonance, $\mathrm{KC} 3=$ negotiation of meaning, $\mathrm{KC} 4=$ testing synthesis, $\mathrm{KC} 5=$ agreement statements and applications, $\mathrm{KC} 6=$ off-topic discussions . 


\section{Difference of discussion sequences among groups}

The above quantitative content analysis provides an understanding of the interaction levels and knowledge construction of different role assignments in the forums. Results for LSA are shown in Figures 4 and 5. Table 11 provides the $z$ score for each discussion sequence. In Figures 4 and 5, each node represents a code of IL or KC, and the arrow connecting to the nodes suggests that the sequential discussion pattern reached statistical significance (with corresponding $z$ score) over other patterns. For example, in full assignment, an arrow from IL3 to IL1 suggests that there was a discussion transition from interactive-elaborative (IL3) to independent (IL1). Moreover, an arrow from KC4 to KC4 suggests there was a discussion continuity in the testing synthesis (KC4) among threads. Only statistically significant sequences are depicted in the figures for clarity.

Table 11

Adjusted residuals (z score) for interaction level and knowledge construction for role assignments

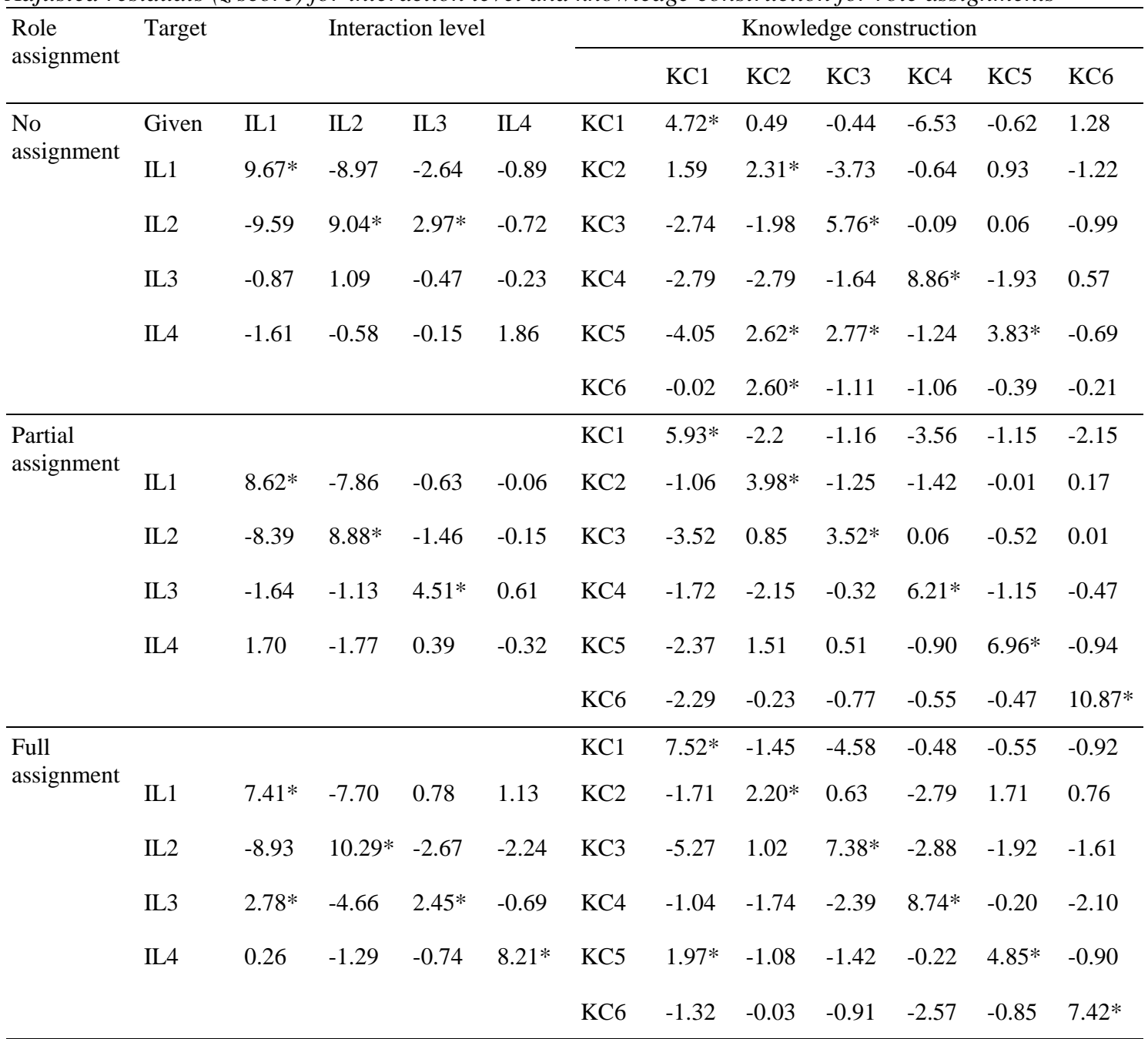

* Denotes $p$ value $<0.05$

Note. IL1 = independent, IL2 = quasi-interactive, IL3 = interactive-elaborative, IL4 = interactive-negotiating; KC1 = sharing and comparing of information, $\mathrm{KC} 2=$ exploration of dissonance, $\mathrm{KC} 3=$ negotiation of meaning, $\mathrm{KC} 4=$ testing synthesis, $\mathrm{KC} 5=$ agreement statements and applications, $\mathrm{KC} 6=$ off-topic discussions.

Several significant discussion patterns were explored in the ILs and KCs. Two discussion continuities, IL1 $\rightarrow$ IL1 (independent) and IL2 $\rightarrow$ IL2 (quasi-interactive) were found in all three assignments. Moreover, the discussion continuity of IL3 (interactive-elaborative) was explored in both partial and full assignments. However, the discussion continuity of IL4 (interactive-negotiating) was only observed in the full assignment group. Although there were two interaction transitions (i.e., IL2 $\rightarrow$ IL3 in no assignment and IL3 $\rightarrow$ IL1 in full assignments), discussants in the summer and spring offerings, regardless of whether 
everyone or only a few had roles, tended to create more focused interactions. This finding indicates that TOL learners were more interactively focused in discussions when role assignments were either partially or fully initiated. We witnessed the continuity of IL3 once a few students were assigned roles and, further, the continuity of IL4 once every student was assigned roles.
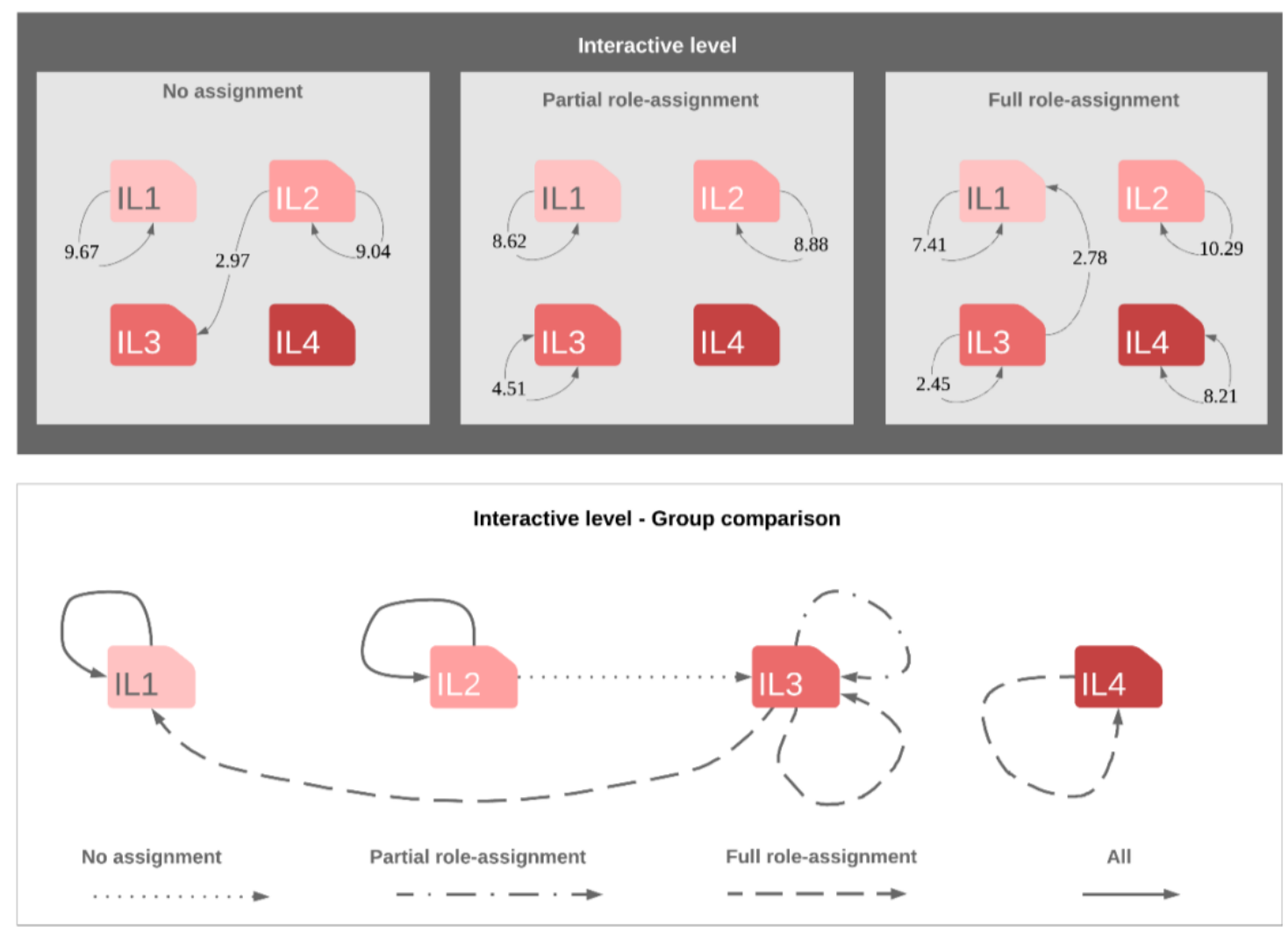

Figure 4. Visualised interaction sequences and comparison in three role assignments

Note. IL1 = independent, IL2 = quasi-interactive, IL3 = interactive-elaborative, IL4 = interactive-negotiating.

Interestingly, focused knowledge construction patterns of TOL learners were observed in all three role assignments. The continuity of five knowledge constructions all reached statistical significance (i.e., KC1 $\rightarrow \mathrm{KC} 1, \mathrm{KC} 2 \rightarrow \mathrm{KC} 2$ ). Moreover, the continuity of off-topic discussions (KC6) was found in both partial and full assignments. By contrast, we discovered three significant discussion transitions in the no assignment group, namely $\mathrm{KC5}$ (agreement statements and applications) $\rightarrow \mathrm{KC} 2$ (exploration of dissonance) and KC3 (negotiation of meaning) and KC6 (off-topic discussions) $\rightarrow \mathrm{KC} 2$. Another discussion transition was borderline observed in the full assignment groups, $\mathrm{KC} 5 \rightarrow \mathrm{KC} 1$ (sharing and comparing of information). This result indicates that when students were assigned roles in forums, they searched and joined discussions with similar knowledge construction levels. More importantly, as long as a few students were assigned roles, the focused effect happened as if every student had been assigned roles. The interpretations and discussions of these results are presented in the following section. 

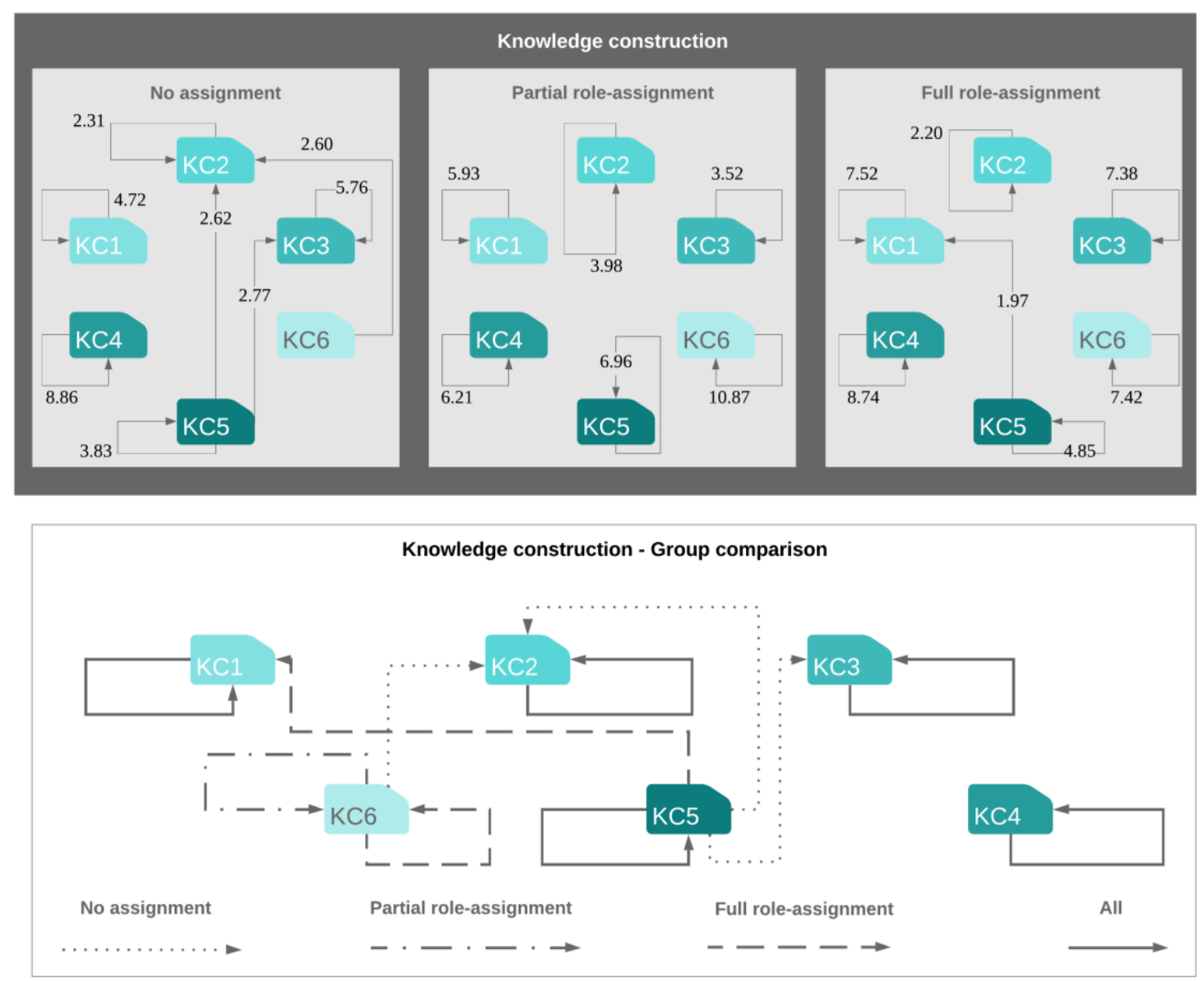

Figure 5. Visualised knowledge construction sequences and comparison in three role assignments Note. $\mathrm{KC} 1$ = sharing and comparing of information, $\mathrm{KC} 2=$ exploration of dissonance, $\mathrm{KC} 3=$ negotiation of meaning, $\mathrm{KC} 4=$ testing synthesis, $\mathrm{KC} 5=$ agreement statements and applications, KC6 $=$ off-topic discussions .

\section{Discussion and conclusion}

This study employed QCA and LSA to explore the interaction and knowledge-construction behaviours among online learners in a MOOC that involved role-assignment strategies in asynchronous discussion forums during 2017 to 2020 . The course was TOL, which features meta-learning strategies; the roles assigned in the study were starter, moderator, theoretician, source searcher, and summariser. Three fall offerings had no role assignments, three spring offerings adapted partial role-assignments, and two summer offerings adapted full role-assignments. After eight iterative course offerings, we retrieved 5,439 posts. We coded, analysed and visualised both the content structures and discussion sequences of the TOL learners' overall knowledge construction and their interactions. Based on these findings, the following section discusses and proposes suggestions for MOOCs instructors adopting role-assignment strategies.

\section{The effectiveness of partial role-assignments in online discussion}

Our findings indicate differences in both frequencies of discussion messages and discussion patterns among the three role-assignment groups. When comparing the posting frequencies, results show that summer students (for-credit) on average posted more than interest-based MOOC learners $\left(\mathrm{M}_{\text {Full }}=9.90\right.$ vs. $\mathrm{M}_{\mathrm{No}}=$ 0.54; see Table 5). The most significant finding, however, was that the average posts of spring students doubled $\left(\mathrm{M}_{\text {Partial }}=1.19\right.$ vs. $\left.\mathrm{M}_{\mathrm{No}}=0.54\right)$ after we blended in a dozen of the role-assigned students, and they participated together with the ordinary interest-based MOOC learners.

Both full- and partial-assignment groups performed at higher interaction levels than the no-assignment group. Similarly, full- and partial-assignment groups performed higher knowledge construction levels than no-assignment groups. Assigning roles again was supported as an effective strategy, and our results are 
consistent with previous studies (Cheng et al., 2014; De Wever et al., 2008, 2009; Friend Wise et al., 2012; Gu et al., 2015; Yilmaz \& Yilmaz, 2019). Moreover, interaction and knowledge-construction sequences appeared differently among the three groups. Overall, learners who had roles assigned to them tended to focus on the specific level of interaction or specific knowledge construction, whereas the no-assignment group performed diffused discussions. Research has also found that role-assigned students showed similar discussion continuity in knowledge construction: KC2 in Hou (2012); KC1, KC2, KC3 and KC6 in S. M. Wang et al. (2016). Our findings and previous studies consistently show that assigning roles is valuable in forum discussions. Taken one step further, our findings suggest that we can assign as few as $2 \%$ of the roleassigned students among learners, and their discussion interaction and knowledge construction will improve as if all learners were given roles in discussions.

\section{Forum engagement and pass rate in MOOCs}

It is generally understood that higher forum engagement leads to better student performance and retention in online courses (e.g., Friend Wise \& Cui, 2018). Moreover, improving learners' metacognition improves learners' interest in continuing to learn in MOOCs (Tsai, Lin, Hong, \& Tai, 2018). The vital few students in partial role-assignment of the present study served as cognitive scaffolds and facilitated the whole class greatly in forum engagement. Interestingly, however, the average pass rates in the no-assignments group and the partial-assignments group were somewhat similar (c.f. $12.2 \%$ and $13.4 \%$ respectively; see Table 5).

Earlier MOOC literature tended to view course non-completion as a problem to course success (Bozkurt et al., 2017; Veletsianos \& Shepherdson, 2016), but misplaced traditionally good student measures (e.g., passing with high grades) to this free and open space of learning (DeBoer et al., 2014). Despite consistent participation by wholly engaged and least engaged MOOC learners across courses, a prototypical study of MOOC learners yields a third cluster of learners (Deng et al., 2020): individually (non-socially) engaged learners. Their behavioural, cognitive and emotional engagement may be as high as the wholly engaged learners who are likely to earn the course certificate. However, the individually engaged learners only participate in a subset of the MOOC and never reach completion. Poquet et al.'s (2020) sequential study on MOOC discussions saw two profiles of learners: visitors and residents with different learning commitments. Unlike traditional college-level online learners, the visitors view the MOOC as a grab-andgo marketplace for information that interests them (de Freitas et al., 2015) and they leave the course anytime that their expectations have been met (Poquet et al., 2020). In our study, the partial role-assignment may have encouraged a portion of visitors to participate actively in forum discussions to some extent. However, being engaged in forums did not necessarily encourage them to complete the course and obtain certificates.

\section{Educational significances and implications}

In this paper, we have analysed these discussion patterns and the results provide specific suggestions for MOOCs instructors regarding how to improve learners' knowledge construction and interaction using asynchronous discussions. Instructors may select as few as a dozen learners, assign them rotated roles and orient them with proper role descriptions (Yilmaz \& Yilmaz, 2019). Most importantly, these learners act behind the scenes and become the vital hidden but stimulating figures in MOOC discussion forums.

\section{Limitations and future research}

This study is not without limitations. For example, we did not qualitatively analyse the threads and interpret what learners gained from the forums. Besides, although we learned that the partial role-assignment strategy will ease MOOC instructors' efforts in promoting effective forum discussions, the instructors may still be challenged in by finding those vital few at the beginning of the course. Based on our findings, we propose a suggestion for further researchers: focusing on developing prediction models that will match MOOC learners whose posting characteristics are close to a certain role (e.g., summariser) in the beginning of the course. MOOC instructors could then contact these matched learners and ask them to contribute to discussions based on roles. MOOC instructors could leverage the support from this early-headhunting artificial intelligence tool, locate and reach out to the vital few students and implement the partial roleassignment strategy for better forum discussions. 


\section{Acknowledgements}

This work was supported by Taiwan's Ministry of Science and Technology (grant numbers MOST 1062511-S-009-004- and MOST 107-2511-H-009-006-MY2). The funding agency had no involvement in this research. The authors would like to thank Ching-Yu Tseng (mini012100@gmail.com), the lead teaching assistant of TOL, as well as the anonymous reviewers for their thoughtful comments on this work.

\section{References}

Ak, Ş. (2016). The role of technology-based scaffolding in problem-based online asynchronous discussion. British Journal of Educational Technology, 47, 680-693. https://doi.org/10.1111/bjet.12254

Ash, K. (2012, June 13). Colleges use 'digital badges' to replace traditional grading. Education Week. https://www.edweek.org/teaching-learning/colleges-use-digital-badges-to-replace-traditionalgrading/2012/06

Avc1, Ü. (2020). Examining the role of sentence openers, role assignment scaffolds and selfdetermination in collaborative knowledge building. Educational Technology Research and Development, 68(1), 109-135. https://doi.org/10.1007/s11423-019-09672-5

Bakeman, R., \& Gottman, J. M. (1997). Observing interaction: An introduction to sequential analysis (2nd ed). Cambridge University Press.

Berge, Z. L. (1995). Facilitating computer conferencing: Recommendations from the field. Educational Technology, 35(1), 22-30. https://www.jstor.org/stable/44428247

Bozkurt, A., Akgün-Özbek, E., \& Zawacki-Richter, O. (2017). Trends and patterns in massive open online courses: Review and content analysis of research on MOOCs (2008-2015). The International Review of Research in Open and Distributed Learning, 18(5). https://doi.org/10.19173/irrodl.v18i5.3080

Breslow, L., Pritchard, D. E., DeBoer, J., Stump, G. S., Ho, A. D., \& Seaton, D. T. (2013). Studying learning in the worldwide classroom research into edX's first MOOC. Research \& Practice in Assessment, 8, 13-25. http://www.rpajournal.com/studying-learning-in-the-worldwide-classroomresearch-into-edxs-first-mooc/

Chen, K.-Z., \& Oakley, B. (2020). Redeveloping a global MOOC to be more locally relevant: Designbased research. International Journal of Educational Technology in Higher Education, 17(9). https://doi.org/10.1186/s41239-020-0178-6

Cheng, B., Wang, M., \& Mercer, N. (2014). Effects of role assignment in concept mapping mediated small group learning. The Internet and Higher Education, 23, 27-38. https://doi.org/10.1016/j.iheduc.2014.06.001

Cohen, A., Shimony, U., Nachmias, R., \& Soffer, T. (2019). Active learners' characterization in MOOC forums and their generated knowledge. British Journal of Educational Technology, 50(1), 177-198. https://doi.org/10.1111/bjet.12670

Cohen, E. G. (1994). Restructuring the classroom: Conditions for productive small groups. Review of Educational Research, 64(1), 1-35. https://doi.org/10.1186/s41239-020-0178-6

Conaway, R. N., Easton, S. S., \& Schmidt, W. V. (2005). Strategies for enhancing student interaction and immediacy in online courses. Business Communication Quarterly, 68(1), 23-35. https://doi.org/10.1177/1080569904273300

Dawson, S. (2006). A study of the relationship between student communication interaction and sense of community. The Internet and Higher Education, 9(3), 153-162. https://doi.org/10.1016/j.iheduc.2006.06.007

DeBoer, J., Ho, A. D., Stump, G. S., \& Breslow, L. (2014). Changing “course": Reconceptualizing educational variables for massive open online courses. Educational Researcher, 43(2), 74-84. https://doi.org/10.3102/0013189X14523038

De Freitas, S. I., Morgan, J., \& Gibson, D. (2015). Will MOOCs transform learning and teaching in higher education? Engagement and course retention in online learning provision. British Journal of Educational Technology, 46, 455-471. https://doi.org/10.1111/bjet.12268

Deng, R., Benckendorff, P., \& Gannaway, D. (2020). Linking learner factors, teaching context, and engagement patterns with MOOC learning outcomes. Journal of Computer Assisted Learning. https://doi.org/10.1111/JCAL.12437 
Dennen, V. P. (2005). From message posting to learning dialogues: Factors affecting learner participation in asynchronous discussion. Distance Education, 26(1), 127-148. https://doi.org/10.1080/01587910500081376

Dennen, V. P., Darabi, A. A., \& Smith, L. J. (2007). Instructor-learner interaction in online courses: The relative perceived importance of particular instructor actions on performance and satisfaction. Distance Education, 28(1), 65-79. https://doi.org/10.1080/01587910701305319

De Wever, B., Schellens, T., Van Keer, H., \& Valcke, M. (2008). Structuring asynchronous discussion groups by introducing roles: Do students act in line with assigned roles? Small Group Research, 39(6), 770-794. https://doi.org/10.1177/1046496408323227

De Wever, B., Van Keer, H., Schellens, T., \& Valcke, M. (2009). Structuring asynchronous discussion groups: the impact of role assignment and self-assessment on students' levels of knowledge construction through social negotiation. Journal of Computer Assisted Learning, 25(2), 177-188. https://doi.org/10.1111/j.1365-2729.2008.00292.x

Doyle, W. (1986). Classroom organization and management. In M. C. Wittrock (Ed.), Handbook of research on teaching (pp. 392-431). Macmillan.

Dubovi, I., \& Tabak, I. (2020). An empirical analysis of knowledge co-construction in YouTube comments. Computers \& Education, 156, Article 103939. https://doi.org/10.1016/j.compedu.2020.103939

Ellis, R. A., \& Calvo, R. (2004). Learning through discussions in blended environments. Educational Media International, 41(3), 263-274. https://doi.org/10.1080/09523980410001680879

Farrokhnia, M., Pijeira-Díaz, H. J., Noroozi, O., \& Hatami, J. (2019). Computer-supported collaborative concept mapping: The effects of different instructional designs on conceptual understanding and knowledge co-construction. Computers \& Education, 142, Article 103640. https://doi.org/10.1016/j.compedu.2019.103640

Floren, L. C., ten Cate, O., Irby, D. M., \& O'Brien, B. C. (2020). An interaction analysis model to study knowledge construction in interprofessional education: Proof of concept. Journal of Interprofessional Care, 35, 1-8. https://doi.org/10.1080/13561820.2020.1797653

Friend Wise, A., \& Cui, Y. (2018). Learning communities in the crowd: Characteristics of content related interactions and social relationships in MOOC discussion forums. Computers \& Education, 122, 221242. https://doi.org/10.1016/j.compedu.2018.03.021

Friend Wise, A., \& Paulus, T. M. (2016). Analyzing learning in online discussions. In C. Haythornthwaite, R. Andrews, J. Fransman \& E. M. Meyers (Eds.), The SAGE handbook of elearning research (2nd ed., pp. 270-290). Sage. https://doi.org/10.4135/9781529716696.n14

Friend Wise, A., Saghafian, M., \& Padmanabhan, P. (2012). Towards more precise design guidance: Specifying and testing the functions of assigned student roles in online discussions. Educational Technology Research and Development, 60, 55-82. https://doi.org/10.1007/s11423-011-9212-7

Gall, M. D., \& Gall, J. P. (1976). The discussion method. The Psychology of Teaching Methods, 75, 166216.

Gambrell, L. B. (2004). Shifts in the conversation: Teacher-led, peer-led, and computer-mediated discussions. The Reading Teacher, 58(2), 212-215. https://doi.org/10.1598/RT.58.2.9

Garrison, D. R. (2017). E-learning in the 21 st century: A community of inquiry framework for research and practice (3rd ed.). Routledge.

Garrison, D. R., \& Cleveland-Innes, M. (2005). Facilitating cognitive presence in online learning: Interaction is not enough. The American Journal of Distance Education, 19(3), 133-148. https://doi.org/10.1207/s15389286ajde1903_2

Garrison, D. R., Cleveland-Innes, M., \& Fung, T. S. (2010). Exploring causal relationships among teaching, cognitive and social presence: Student perceptions of the community of inquiry framework. The Internet and Higher Education, 13(1-2), 31-36. https://doi.org/10.1016/j.iheduc.2009.10.002

Gu, X., Shao, Y., Guo, X., \& Lim, C. P. (2015). Designing a role structure to engage students in computer-supported collaborative learning. The Internet and Higher Education, 24, 13-20. https://doi.org/10.1016/j.iheduc.2014.09.002

Guasch, T., Espasa, A., \& Martinez-Melo, M. (2019). The art of questioning in online learning environments: The potentialities of feedback in writing. Assessment \& Evaluation in Higher Education, 44(1), 111-123. https://doi.org/10.1080/02602938.2018.1479373

Gunawardena, C. N., Lowe, C. A., \& Anderson, T. (1997). Analysis of a global online debate and the development of an interaction analysis model for examining social construction of knowledge in computer conferencing. Journal of Educational Computing Research, 17(4), 397-431.

https://doi.org/10.2190\%2F7MQV-X9UJ-C7Q3-NRAG 
Hara, N., Bonk, C. J., \& Angeli, C. (2000). Content analysis of online discussion in an applied educational psychology course. Instructional Science, 28(2), 115-152. https://doi.org/10.1023/A:1003764722829

Henri, F. (1992). Computer conferencing and content analysis. In A. R. Kaye (Ed.), Collaborative learning through computer conferencing: The Najaden papers (pp. 117-136). Springer-Verlag. https://doi.org/10.1007/978-3-642-77684-7_8

Hew, K. F., \& Cheung, W. S. (2014). Students' and instructors' use of massive open online courses (MOOCs): Motivations and challenges. Educational Research Review, 12, 45-58. https://doi.org/10.1016/j.edurev.2014.05.001

Hill, J. R., Song, L., \& West, R. E. (2009). Social learning theory and web-based learning environments: A review of research and discussion of implications. The American Journal of Distance Education, 23(2), 88-103. https://doi.org/10.1080/08923640902857713

Hooper, S., \& Hannafin, M. J. (1988). Cooperative CBI: The effects of heterogeneous versus homogeneous grouping on the learning of progressively complex concepts. Journal of Educational Computing Research, 4(4), 413-424. https://doi.org/10.2190/T26C-3FTH-RNYP-TV30

Hou, H. T. (2012). Analyzing the learning process of an online role-playing discussion activity. Educational Technology \& Society, 15(1), 211-222. http://www.jstor.org/stable/jeductechsoci.15.1.211

Hou, H. T. (2015). Integrating cluster and sequential analysis to explore learners' flow and behavioural patterns in a simulation game with situated-learning context for science courses: A video-based process exploration. Computers in Human Behavior, 48(3), 424-435. https://doi.org/10.1016/j.compedu.2011.02.012

Hou, H. T. (2015). Integrating cluster and sequential analysis to explore learners' flow and behavioural patterns in a simulation game with situated-learning context for science courses: A video-based process exploration. Computers in Human Behavior, 48(3), 424-435. https://doi.org/10.1016/j.compedu.2011.02.012

Hou, H. T., \& Wu, S. Y. (2011). Analyzing the social knowledge construction behavioral patterns of an online synchronous collaborative discussion instructional activity using an instant messaging tool: A case study. Computers \& Education, 57, 1459-1468. https://doi.org/10.1016/j.compedu.2011.02.012

Hung, D., Tan, S. C., \& Chen, D. T. (2005). How the internet facilitates learning as dialog: Design considerations for online discussions. International Journal of Instructional Media, 32(1), 37-46. https://www.learntechlib.org/p/64248

Jiang, S., Smith, B. E., \& Shen, J. (2019). Examining how different modes mediate adolescents' interactions during their collaborative multimodal composing processes. Interactive Learning Environments. https://doi.org/10.1080/10494820.2019.1612450

Jiang, W. (2017). Interdependence of roles, role rotation, and sense of community in an online course. Distance Education, 38(1), 84-105. https://doi.org/10.1080/01587919.2017.1299564

Jordan, K. (2011). Do beginning teachers know how to participate and interact in online discussion? Outcomes from a Victorian case study. Australasian Journal of Educational Technology, 27(7). https://doi.org/10.14742/ajet.915

Khalil, H., \& Ebner, M. (2014). MOOCs completion rates and possible methods to improve retention: A literature review. In J. Viteli \& M. Leikmaa (Eds.), Proceedings of the World Conference on Educational Media and Technology (pp. 1305-1313). Association for the Advancement of Computing in Education. https://learntechlib.org/d/147656

Lai, K. W. (2015). Knowledge construction in online learning communities: A case study of a doctoral course. Studies in Higher Education, 40(4), 561-579. https://doi.org/10.1080/03075079.2013.831402

Lämsä, J., Hämäläinen, R., Koskinen, P., Viiri, J., \& Mannonen, J. (2020). The potential of temporal analysis: Combining log data and lag sequential analysis to investigate temporal differences between scaffolded and non-scaffolded group inquiry-based learning processes. Computers \& Education, 143, Article 103674. https://doi.org/10.1016/j.compedu.2019.103674

Lave, J., \& Wenger, E. (1991). Situated learning: Legitimate peripheral participation. Cambridge University Press. https://doi.org/10.1017/CBO9780511815355

Leskens, J. G., Brugnach, M., \& Hoekstra, A. (2019). How do interactive flood simulation models influence decision-making? An observations-based evaluation method. Water, 11, Article 2427. https://doi.org/10.3390/w11112427

Marra, R. M., Moore, J. L., \& Klimczak, A. K. (2004). Content analysis of online discussion forums: A comparative analysis of protocols. Educational Technology Research and Development, 52(2), $23-40$. https://doi.org/10.1007/BF02504837 
Mazzolini, M., \& Maddison, S. (2003). Sage, guide or ghost? The effect of instructor intervention on student participation in online discussion forums. Computers \& Education, 40(3), 237-253. https://doi.org/10.1016/S0360-1315(02)00129-X

Meyer, K. A. (2003). Face-to-face versus threaded discussions: The role of time and higher-order thinking. Journal of Asynchronous Learning Networks, 7(3), 55-65. https://doi.org/10.24059/olj.v7i3.1845

Moore, M. G. (1972). Learner autonomy: The second dimension of independent learning. Convergence, 5(2), 76-88.

Moore, M. G. (1989). Three types of interaction [Editorial]. American Journal of Distance Education, 3(2), 1-7. https://doi.org/10.1080/08923648909526659

Moore, M. G. (1997). Theory of transactional distance. In D. Keegan (Ed.), Theoretical principles of distance education (pp. 22-38). Routledge.

Murphy, E. (1997). Constructivism: From philosophy to practice (ED444966). ERIC. http://files.eric.ed.gov/fulltext/ED444966.pdf

Oren, A., Mioduser, D., \& Nachmia, R. (2002). The development of social climate in virtual learning discussion groups. The International Review of Research in Open and Distributed Learning, 3(1). https://doi.org/10.19173/irrodl.v3i1.80

Orsolini, M., \& Pontecorvo, C. (1992). Children's talk in classroom discussions. Cognition and Instruction, 9(2), 113-136. https://doi.org/10.1207/s1532690xci0902_2

Palloff, R. M., \& Pratt, K. (1999). Building learning communities in cyberspace: Effective strategies for the online classroom. Jossey-Bass.

Pena-Shaff, J. B., \& Nicholls, C. (2004). Analyzing student interactions and meaning construction in computer bulletin board discussions. Computers \& Education, 42(3), 243-265. https://doi.org/10.1016/j.compedu.2003.08.003

Poquet, O., Joksimovic, S., \& Dawson, S. (2020). Differences in forum communication of residents and visitors in MOOCS. Computers \& Education, 156, Article 103937. https://doi.org/10.1016/j.compedu.2020.103937

Rafaeli, S., \& Sudweeks, F. (1997). Networked interactivity. Journal of Computer-Mediated Communication, 2(4). https://doi.org/10.1111/j.1083-6101.1997.tb00201.x

Rehm, M., Mulder, R. H., Gijselaers, W., \& Segers, M. (2016). The impact of hierarchical positions on the type of communication within online communities of learning. Computers in Human Behaviour, 58, 158-170. https://doi.org/10.1016/j.chb.2015.12.065

Reimann, P., Markauskaite, L., \& Bannert, M. (2014). e-Research and learning theory: What do sequence and process mining methods contribute? British Journal of Educational Technology, 45(3), 528-540. https://doi.org/10.1111/bjet.12146

Rourke, L., \& Anderson, T. (2004). Validity in quantitative content analysis. Education Technology Research and Development, 52(1), 5-18. https://link.springer.com/article/10.1007/BF02504769

Saah, D. (2020, November 30). By the numbers: MOOCs in 2020. The Report. https://www.classcentral.com/report/mooc-stats-2020/

Schellens, T., Van Keer, H., \& Valcke, M. (2005). The impact of role assignment on knowledge construction in asynchronous discussion groups: A multilevel analysis. Small Group Research, 36(6), 704-745. https://doi.org/10.1177/1046496405281771

Schellens, T., Van Keer, H., De Wever, B., \& Valcke, M. (2007). Scripting by assigning roles: Does it improve knowledge construction in asynchronous discussion groups? International Journal of Computer-Supported Collaborative Learning, 2(2-3), 225-246. https://doi.org/10.1007/s11412-0079016-2

Shin, Y., \& Jung, J. (2020). The effects of a visible-annotation tool for sequential knowledge construction on discourse patterns and collaborative outcomes. Australasian Journal of Educational Technology, 36(4), 57-71. https://doi.org/10.14742/ajet.4875

Shin, Y., Kim, D., \& Song, D. (2020). Types and timing of scaffolding to promote meaningful peer interaction and increase learning performance in computer-supported collaborative learning environments. Journal of Educational Computing Research, 58, 640-661. https://doi.org/10.1177/0735633119877134

Smith, K. B., \& Shotsberger, P. G. (1997). Assessing the use of graphing calculators in college algebra: Reflecting on dimensions of teaching and learning. School Science and Mathematics, 97(7), 368-376. https://doi.org/10.1111/j.1949-8594.1997.tb17378.x

Sproull, L., \& Kiesler, S. (1986). Reducing social context cues: Electronic mail in organizational communications. Management Science, 32, 1492-1512. https://doi.org/10.1287/mnsc.32.11.1492 
Stacey, E. (1999). Collaborative learning in an online environment. International Journal of E-Learning \& Distance Education, 14(2), 14-33. http://www.ijede.ca/index.php/jde/article/view/154/379

Steffe, L. P., \& Gale, J. E. (1995). Constructivism in education. Lawrence Erlbaum Associates. https://doi.org/10.4324/9780203052600

Strijbos, J.-W., Martens, R. L., Jochems, W. M. G., \& Broers, N. J. (2004). The effect of functional roles on group efficiency: Using multilevel modeling and content analysis to investigate computersupported collaboration in small groups. Small Group Research, 35(2), 195-229. https://doi.org/10.1177/1046496403260843

Sun, J. C. Y., Kuo, C. Y., Hou, H. T., \& Lin, Y. Y. (2017). Exploring learners' sequential behavioral patterns, flow experience, and learning performance in an anti-phishing educational game. Educational Technology \& Society, 20(1), 45-60.

Swan, K., Shen, J., \& Hiltz, S. R. (2006). Assessment and collaboration in online learning. Journal of Asynchronous Learning Networks, 10(1), 45-62. https://doi.org/10.24059/olj.v10i1.1770

Thomas, M. J. W. (2002). Learning within incoherent structures: The space of online discussion forums. Journal of Computer Assisted Learning, 18(3), 351-366. https://doi.org/10.1046/j.02664909.2002.03800.x

Tiene, D. (2000). Online discussions: A survey of advantages and disadvantages compared to face-to-face discussions. Journal of Educational Multimedia and Hypermedia, 9(4), 371-384. https://www.learntechlib.org/primary/p/9551/

Tsai, Y.-H., Lin, C.-H., Hong, J.-C., \& Tai, K.-H. (2018). The effects of metacognition on online learning interest and continuance to learn with MOOCs. Computers \& Education, 121, 18-29. https://doi.org/10.1016/j.compedu.2018.02.011

University of Illinois at Urbana-Champaign. (2013). Guide to massive open online courses (MOOCs) at Illinois. http://moocs.illinois.edu/docs/moocs-at-illinois-guide.pdf

Vanderbilt University. (n.d.). Coursera resource guide. https://cft.vanderbilt.edu/wpcontent/uploads/sites/59/coursera.pdf

Veerman, A., \& Veldhuis-Diermanse, E. (2001). Collaborative learning through computer-mediated communication in academic education. In P. Dillenbourg, A. Eurelings, \& K. Hakkarainen (Eds.), European perspectives on computer-supported collaborative learning-Proceedings of the First European Conference on Computer Supported Collaborative Learning (pp. 625-632). The International Society of the Learning Sciences. https://www.isls.org/cscl/Euro2001/Papers/166.doc

Veletsianos, G., \& Shepherdson, P. (2016). A systematic analysis and synthesis of the empirical MOOC literature published in 2013-2015. The International Review of Research in Open and Distributed Learning, 17(2). https://doi.org/10.19173/irrodl.v17i2.2448

Wang, C.-W. (2017, September 28). 網路造就終身學習社會，線上學霸就看這裡！[Creating lifelong learning society with MOOC learners]. ewant newsletter. https://hero.nctu.edu.tw/mooc/?p=978\&lang=zh

Wang, S. M., Hou, H. T., \& Wu, S. Y. (2016). Analyzing the knowledge construction and cognitive patterns of blog-based instructional activities using four frequent interactive strategies (problem solving, peer assessment, role playing and peer tutoring): A preliminary study. Educational Technology Research \& Development, 65, 301-323. https://doi.org/10.1007/s11423-016-9471-4

Weinberger, A., \& Fischer, F. (2006). A framework to analyze argumentative knowledge construction in computer-supported collaborative learning. Computers \& Education, 46(1), 71-95. https://doi.org/10.1016/j.compedu.2005.04.003

Wenger, E. (1998). Communities of practice: Learning, meaning, and identity. Cambridge University Press.

Wood, D., Bruner, J. S., \& Ross, G. (1976). The role of tutoring in problem solving. Journal of Child Psychology and Psychiatry, 17(2), 89-100. https://doi.org/10.1111/j.1469-7610.1976.tb00381.x

Wu, S. Y., \& Hou, H. T. (2015). How cognitive styles affect the learning behaviors of online problemsolving based discussion activity: A lag sequential analysis. Journal of Educational Computing Research, 52(2), 277-298. https://doi.org/10.1177/0735633115571307

Wu, S. Y., Chen, S. Y., \& Hou, H. T. (2016). Exploring the interactive patterns of concept map-based online discussion: A sequential analysis of users' operations, cognitive processing, and knowledge construction. Interactive Learning Environments, 24(8), 1778-1794. https://doi.org/10.1080/10494820.2015.1057740

Yeh, H.-H, \& Chen, K.-Z, (2019, August 5-8). Promoting knowledge constructive discussion in massive open online courses: A role-assignment intervention [Poster presentation]. World Education Research Association 2019 Focal Meeting, Tokyo, Japan. 
Yilmaz, R., \& Yilmaz, F. G. K. (2019). Assigned roles as a structuring tool in online discussion groups: Comparison of transactional distance and knowledge sharing behaviors. Journal of Educational Computing Research, 57, 1303-1325. https://doi.org/10.1177/0735633118786855

Yoon, S. A., Miller, K., Richman, T., Wendel, D., Schoenfeld, I., Anderson, E., \& Shim, J. (2020). Encouraging collaboration and building community in online asynchronous professional development: Designing for social capital. International Journal of Computer-Supported Collaborative Learning, 15, 351-371. https://doi.org/10.1007/s11412-020-09326-2

Zheng, B., \& Warschauer, M. (2019). Language development and epistemic engagement among upper elementary students in synchronous computer-mediated communication. Journal of Educational Computing Research, 57, 1549-1574. https://doi.org/10.1177/0735633118794059

Zheng, L., \& Yu, J. (2016). Exploring the behavioral patterns of coregulation in mobile computersupported collaborative learning. Smart Learning Environments, 3(1), 1-20. https://doi.org/10.1186/s40561-016-0024-4

Zhu, M., Sari, A., \& Lee, M. M. (2018). A systematic review of research methods and topics of the empirical MOOC literature (2014-2016). The Internet and Higher Education, 37, 31-39. https://doi.org/10.1016/j.iheduc.2018.01.002

Zhu, M., Sari, A., \& Lee, M. M. (2020). A comprehensive systematic review of MOOC research: Research techniques, topics, and trends from 2009 to 2019. Educational Technology Research and Development, 68, 1685-1710. https://doi.org/10.1007/s11423-020-09798-x

Zhu, P. (1998). Learning and mentoring: Electronic discussion in a distance learning course. In C. J. Bonk \& K. S. King (Eds.), Electronic collaborators: Learner-centered technologies for literacy, apprenticeship, and discourse (pp. 233-259). Erlbaum.

Corresponding author: Ken-Zen Chen, kenzenchen@nctu.edu.tw

Copyright: Articles published in the Australasian Journal of Educational Technology (AJET) are available under Creative Commons Attribution Non-Commercial No Derivatives Licence (CC BYNC-ND 4.0). Authors retain copyright in their work and grant AJET right of first publication under CC BY-NC-ND 4.0.

Please cite as: Chen, K.-Z., \& Yeh, H.-H. (2021). Acting in secret: Interaction, knowledge construction and sequential discussion patterns of partial role-assignment in a MOOC. Australasian Journal of Educational Technology, 37(6), 41-60. https://doi.org/10.14742/ajet.6979 